\title{
Similarities between Albanian and Romanian in the Entire Language Subsystems
}

\author{
Mimoza Karagjozi Kore \\ Associate Professor, Lecturer, \\ Department of Albanian language, \\ Faculty of History and Philology, Tirana University, Albania. \\ E-mail:mimo.kore@gmail.com
}

\section{Doi:10.5901/mjss.2013.v4n2p175}

\begin{abstract}
In this study of theoritical character, the sight is set on the most typical similtudes between Albanian and Romanian observed in the entire language subsystems. There turn out to be common features only for these two languages which are different from overall Balkan features (Balcan shpracbund). This article points out not only the parallelisms previously noticed by many linguists over centuries during the evolution of these two languages independently of each other, but also the latest common points recently observed. The causes of these phenomena are given at the end of the article.Similarties between Albanian and Romanian languages come as a result of Illyrians and Trachians being in contact for centuries before Slavs were established in Balkans.
\end{abstract}

Key words: linguistc relations, Albanian and Romanian languages, phonetic features, grammatical similiarities, syntax, phraseology.

\section{Introduction}

The identification and the explanation of the origin of common linguistic features of Albanian and Romanian languages are related to the problem of ethnogenesis of the two relevant nations. The studies are often cloaked by obscure and logicist reasoning, thus creating confusion about the nature of these relationships, the time and the geographical environment where they were created. Lack of documentation for the non Greek part of the ancient Balkans was the main cause leading to an unfair reasoning. On the other hand both these languages have a later written documentation (approximately at the same time) ${ }^{1}$.

This late documentation led many researchers to erroneous conclusions regarding the origin of the Albanian language, which they related either to Illyrian or Trachi Dacian.On the other hand the Albanian scholars during the past regime didn't have enough academic freedom to come to objective conclusions.

\section{Literature review}

The similarities between Albanian and Romanian have become an object of study in many works. At the beginning of our century, B. P Haşdeu (1901) was concerned about the Romanian language paralatine period. He noticed that the linguistic heritage of Romanian found similiarities with the Albanian language during this period. This led to the conclusion that this similarity did not stem from any other language, nor was it formed in the course of time, but might have been sought in the origin of these languages. Various Romanian researchers like Capidan (1921), Philippide (1927), Rosetti (1930), Dimitrescu (1967), Coteanu (1981) Brâncuş (1978) etc, dealt with the relations between the two languages as well as distinguished Albanian linguists like Çabej (1975), Demiraj (1986), Domi (1988).

Brâncuş (1978) has constantly worked for years to identify the origin of Romanian language and he confirms that even though a lot of effort was put by Romanian linguists, the search doesn't lead to any conclusive evidence. The native aspect of the Romanian language remains an enigma.

\footnotetext{
${ }^{1}$ The oldest text in Rumanian is a letter written in the Cyrillic alphabet of June 1521, in which Neacşu of Câmpulungu writes to the ruler
} of Braşov about a possible attack of the turks. The Albanian language has been documented since 1462 with the Baptism Formula. 
E. Çabej (1975) came to the conclusion that during medival times before Slavs came to Balkans; the early cradle of Albanians was neighbor with the ancient Romanins.

Nowdays, researchers like Matzinger (2005), R. Ismaili (2012), M. A. Gabinschi, Chişinău (2012), etc, have brought the attention back to this topis.

E. Cabej (1975) has noticed that there have been great similarities between the two languages, observed in the close parallelism, in the pronounciation and historic development of sounds, found also in the morphological structure, not only in flexion but also in word formation, noun, verb, preposition's syntax, in sentence building and even in phraseologies and proverbial expressions.

An important moment in the history of these two languages is the influence that Latin language had on them. In Romanian, the phonetic developments as well as the semantic elements of Latin, (in some cases, not always) have more similarities with Albanian than with other Roman languages. Many linguists have regarded this topic in their works like Mihǎescu (1966), Hirt (1967), Çabej (1977), Pelegrini (1982), Ismajli (1987), Paci (2012), etc. The reasoning behind these Latin elements has made it clear other issues like their chronology and periodicity.

The Albanian linguistic science was properly oriented on various viewpoints, taking up the relations between Albanian and Romanian in two aspects:

a. As similiarities of two languages which are part of the Balkan Sprachbund (language area)

b. As similarities, characteristic only for these two languages.

It is understandable that those common features included in part (b), are more important to the history of our two nations and their resctive pelanguage. However, it is difficult to separate those bilingual features from the Balkan ones.

Sandfeld (1930) referring to the shared features as concordances, makes a distinction between "general concordances" and "concordances between various (i.e., individual) Balkan languages".

There have been views that those features belonging to at least three different Balkan languages, bearing no links among them, should be considered as Balkan features.

Georgiev (1968) thought that the main cause of the formation of a linguistic community is interference, i.e., various forms of bilingualism. Çabej (1960) as well endorsed this view, adding that the Balkan linguistics reviews the general analogies and partial concordances. Generally, it is accepted that the common features shared by only two languages should be excluded from the Balkan linguistic community, with the exception of those features that cross the boundaries of the two languages. Herein, this study will describe only the linguistic features that characterize these two languages. It will point out not only the ancient ones, but also the updates that have occurred in the recent centuries, describing them in all subsystems: phonetics, morphology and syntax of the sentence, word formation, vocabulary, proverbs and phraseological phrases. Similtudes in the phonetic and gramatical systems require an internal comparative study method, while those in the vocabulary, phraseological phrases and proverbs are also considered in the framework of outer linguistic impacts.

\section{Analisys}

The common linguistic phenomena of these two languages are noticed too. That is shown

Firstly: in the common phenomena which are found in both Albanian language dialects and the four Romanian dialects, therefore they are formed when these languages were not yet divided into dialects.

Secondly: They were subjected to early phonetic rules which do not function anymore in both languages.

\section{Common features in phonetics:}

- The reduction of vowel / ă / > al. / ë / > rom. / ă /, lî/, a phenomenon observed not only in the inherited element in both languages, but also in the element taken from Latin.

a. in the inherented element of the two languages: al. buzë (lip)-rom. buză; al. i bardhë 'white' - rom. barză;

b. in the latin element there are only two main ways of this vowel acquisition in both languages: spontaneously from unstressed /al which has provided /ë/ as in the words: latin. familia > al. fëmijë 'children' rom. fămeie; latin. camisia > al. këmishë 'shirt' - rom. cămeaşă; latin. sanitatem > al. shëndet 'health'- rom. sănătate etc.

- The second way is the conditioned emergence from a stressed /a/ pronounced in the nasal position: latin. sānctus > rom. sânt, al. shën 'saint' etc. In Romanian it has happened when the sounds /e/ or li/ are positioned after an /r/ or after a labial consonant, such as rău 'bad' < latin. reum; păr 'pear' < latin. pirum etc. 
- $\quad$ The preservation of short latin /ŭ/ for instance: latin. lŭcta> al. Iuftë 'war' rom. luptă; latin. fructus > al. frut 'fruit' rom. frupt; latin. furca 'brush' > m. al. furcë rom. furcă

- $\quad$ he reflection of the latin group /ct/ (Giovine Di P.1982) in al. /ftt/, ljt/, /t/ > rom. /pt/: latin. directus> al. drejt 'towards' rom. dreaptă; latin. fructus> al. frut 'fruit' rom. frupt

- $\quad$ Rhotacism as a dialect feature (Tagliavini, 1932): latin. arena al. tosk. rëra (send); latin. canape > al. kërp 'hemp'; latin. bene> rom. bire

The common features in the grammatical system.

- The back position of the definite article: al.ujk-u 'wolf' rom. lup-ul; al. qen-i 'dog' rom. caine-le; al. vajz-a 'girl' rom. fat-a

- The front position of articles in adjectives: al. njeri i mire 'nice man' rom. omul cel bun

- Formation of some indefinite pronouns: al. kushdo, cilindo 'whoever, every' rum. cineva, cittva;

Some adverbs: al. kudo, kurdo 'everywhere, whenever' rom. undeva, cîndva

al. dikush, cili, diç 'someone, who, something' rom. neşcare, neştine etc.

- Similiarities in numeral formation. Unlike many linguists that stick to the formation of numbers 11-19 due to the Slavic impact jedinū na desete (tracing paper in Romanian unsprezece), G. Brâncuş (2009) believes that this structure has arised as a tracing paper of Balkan Latin unus super decem from the similar structure of the autochtone substract (latin has had undecim).

- There is a parallel formation of the composites of the Romanian and Albanian popular languages: al. kokëmadh 'big head' rom. cap-mare; al. hundëmadh (big nose) rom. nas-mare; al. gojëmbël 'sweet talker' rom. gură-dulce; al. sybardhë 'white eyes' rom. ochi-albi etc. Seeing it from a comparative viewpoint, it is concluded that the composites of this type are identical in both languages, as to the mode of formation, as well as understanding. Such formations are characterized by the absence of the enclitic and proclictic articles of the adjective, something that speaks about their antiquity. The same reasoning is also used by the Albanian scholars Çabej and Cipo (1972).

Nowadays, similiarities are noticed even in adverbs: al. rrallëherë 'rarely' rom. raoreri; al. askund 'nowhere' rom. ascune etc. The compound words in these languages are new formations which lead to the conclusion that similar grammatical structures bring forth common features yet again. Similarities are also noticed in the use of -onia suffix with the nouns of female gender: al. ulkonjë 'female wolf' rom. ursuaie. We have observed similarities in the suffixes of ameliorative words: rom. raţă/răţuş-că-al.roskë 'drake'; rum. căţel/căţel-uş-că al. qenushkë 'little dog' (Karagjozi Kore 2009)

The suffix -zë is one of the ancient suffixes of the Albanian language, found in both dialects which according to (Pasku, 1916) Romanian language borrowed it by Albanian language. That was also observed by Çabej and Xhuvani (1980) who make it clear that this apposition has entered this language together with the Albanian words: rom coacă-ză al. kokë-zë 'small head', rom. pupă-ză al. pupë-zë.

We have noticed from our observations that even an ameliorative or diminutive suffix turns out to be similar in both languages, Albanian and Romanian.: al. lul-kë 'small flower', shqer-kë 'lamb', djal-kë 'boy' fshatar-kë 'village woman', Dhor-kë 'name', korçar-kë 'woman from Korca'. Even in Romanian we find words like: casnică 'shtëpizë-small house', tufcă 'tufëzë-bundle'. It plays the same role in both languages. In Romanian language it is found as an ethnonym, same as the Albanian language: al. shqiptar-kë 'albanian woman' rum. romîncă.

Nowadays, the suffix is widely used in Albanian language -ush, al. engjëll-ush 'name', bab-ush 'father', ar-ush 'bear', vogëlush 'kid'. (Çabej, 1976) draws a comparison with the Romanian -us in words like: lemn-us, (druth). It can be also found in serbo-croatian, but not in the meaning found in both languages we are reviewing in this study: serb. gakusa 'crow'. As regards to its origine there have been various views. Pasku (1960) brings it to Romanian from the Slavic language. Çabej and Xhuvani (1980) think that the Albanian language has inherited it and later on, it came upon the new slavic suffix.

\section{Common features in syntax:}

- The forms of the Subjunctive mood are used when accompanied by the particle le/lë: al. Le të dëgjojmë; (Let's listen) le të ketë; (Let it have) rum. lașă să vie; lașăsă o facă alții

- The subjunctive locution appears the same: le që- lașă că 
- Two participles expressing time and manner relations have a correlative value in the Albanian and Romanian languages: al. duke pare e duke bërë (seeing and doing); rum. vazînd și făcind

- We see word formations, bearing the same structure: al. Kush e di (Who knows?) rum. Cine știe?

\section{Common features in the lexical area:}

There are many common native lexical units in Albanian and Romanian, which should be taken in as a specific relationship of the two languages that have since been in contact. Their earliest usage can be proved:

a. they are scattered throughout the territory of Romania and the major part even in Albania. This distribution regarding the Romanian language is attributable to (Brâncuş 2009), the unitary character of the Danubian Latin, as well as the unity of Romanian social groups in the old times, a unity that was preserved and strengthened under Romanian influence.

b. most of them are used as anthroponyms and toponyms in both languages.

c. the onomastic fund, consisting of them is found in all ancient documents and in dialects.

d. Another distinctive feature is that these units of the autochtonous fund name mainly villages, hills, forests, rivers belonging in general to pastoral realities, farmers' life:

al. avull "vapour" - rom. abur; al. bollë, bullar "copperhead" -rom. balaur "gjarpër-snake"; al. baltë "mud" -rom. baltă; al. bredh "fir"- rom.brad; al. bukur "beautiful" -rom. bukura; al. kësulë "hood" -rom. căciulă; al. katund "village" -rom. cătun; al. qafë "neck" -rom. ceafă; al. sorrë "crow" -rom. cioară; al. çukë "small hill" -rom.ciukă; al. shytë "goat" -rom.ciut; al. kulpër "clematis" rom. curpen; al. flutur "butterfly" -rom. future; al. gjëmb "thorn" -rom. ghimbe; al. gjysh "grandfather" rom. ghiuj; al. grope "hole" -rom. groapă; al. gushë 'neck"-rom. guşă; al. i moshuar "old" -rom. moașă etc.

The linguists do not share similar views on the number of words of common origin. Russu (1970) believes that there are 70 such parallels. Rossetit (1986) says that there are more than 100 units. Brâncuş (2009) brings 89 words and their 535 derivative forms. Albanian linguists have accepted about 70, but in fact today it is generally admitied by linguists that the figures brought by Romanians are more accurate, around 100.

A few words from Slavic have entered both these languages and have been reflected parallel, probably during the first invasions of the Slavic in the Balkans, especially in the field of agriculture, such as: sllav. spade; al. lopatë (spade) rom. lopată;sllav.plough al. plug (plough) rom plug; sllav. sieve al. sita (sieve) rom. sită;sllav. potkovaal. potkua (horseshoe) rom. potcoavă; sllav. trup al. trup rom. trup etc.

Slavic influence is felt more in Romanian than Albanian language, and is even found in common ordinary words like iubi, drag prieten etc. The Slavic extention testifies the ancient existence of these two languages in the eastern and western part of the Balkans.

\section{Similiarities noticed even in phraseological phrases and proverbs;}

Proverbs and wise sayings, words of wisdom, are the product of a historical experience, of the psychology and mentality, material and spiritual culture of a people. Natural phenomena, social life, the lessons and experiences in life have been wisely generalized by various people in different ways, but often related. Such similarities' origin in these two languages should be sought in a wider historical background, but not in interlingual elements, but in outer-lingual circumstances. In our case, they should be seen as a phenomenon arising as a result of mutual influence, coming across frequently and for a long time, before the arrival of the Slavs in the Balkans, which has continued until the $\mathrm{X}$ century, when common Romanian was divided into dialects: rom. Cand doi that ceartă, al treilea castigă. al. Kur zihen dy vetë, fiton një i tretë (when two are fighting, the third one wins); rom. Limba oase n-are, dar oase sfărâmă. al. Gjuha eshtra s'ka, por eshtra thyen (A tongue has no bones, but it can break a heart); rom. Cine sapăgroapa altuia cade el ǐntr-ǐnsa al. Kush $i$ bën gropën tjetrit, bie vetë brenda (The biter bit or the evil deeds will come home to roost); rom. Mai bine târziu decât niciodată al. Më mirë vonë sesa kurrë (better late than never).

\section{Conclusions}

The similarities between the Albanian and Romanian languages are acknowledged by all researchers focusing on this topic. The ethnogenesis of the Albanian language cannot be completely clarified without having a close approach to the same problem in Romanian. To be able to explain ancient language formations in Albanian, there has to be firstly an 
internal comparison and afterwards as a helping element, an external comparios particularily with Romanian. Making clear the origin of these similarities might help resolve the ethnogenesis issue of the two nations and not further blur it.

It's high time the Albanian linguistics acknowledged the existence of a component of the Trachean in the Albanian; apart from the filiation links it has with the Illyrian language. That would explain the similarities at three levels:

i. Inherited similarities in both languages; which come from Thracean and Illyrian.

ii. Similarities obtained independently in both languages; came as a result of former inherited similarities. Due to them, these two langugages developed independently however always under the influence of the old roots.

iii. Similarities as a result of mutual influence. Both languages were in contact with Latin, Slavic and Balkanic Illyrian.

In conlusion, all these similarities must be observed in a broader frame involving political, social and historic factors experienced in the Balkans.

\section{References}

Brîncus, Gr. (1960). Paralele frazeologice romino-albaneze, SCL:11.913-918, Bicureșt.

Brâncuş, Gr. (2009). Kërkime mbi fondin trako-dak të gjuhës rumune, Shtëpia botuese 55, Tirana.

Capidan, Th. (1921). Raporturile albano-române, DR, II, Bucareșt

Coteanu, I. (1981). Originile limbii românâ, Bucureșt

Çabej, E. (1960). Hyrje në historinë e gjuhës shqipe, Tirana

Çabej, E. (1975). Disa mendime mbi marrëdhëniet gjuhësore rumuno-shqiptare, Revista "Studime Filologjike" 1, Tirana

Çabej, E. (1977) Studime gjuhwsore, IV, Botimet Rilindja, Prishtine

Çabej, E., and Xhuvani. A. (1980). Prapashtesat në gjuhën shqipe, Vepra.1, Tirana

Dançetoviq, V. (1960). Prapashtesat diminutive tek emrat në gjuhën shqipe, Prishtina

Demiraj, Sh. (1986). Gramatika historike e gjuhës shqipe, Tirana

Dimitrescu, H. (1967). Introducere în fonetica istoricǎ a limbii române, Bicureșt

Domi, M. (1968). Concordances et analogies syntaxiques albano-roumaines, "Actes du premier Congres Inernat. des e'tudes balkaniques et sud-est europenes" Sofia

Georgiev, V. (1968) Georgiev, Vladimir. Le probleme de l'union linguistique balkanique.,Actes VI.

Giovine Di P. (1982). II gruppo ct latino in albanese, Istituto di Glottologia, Universita' di Roma

Hașdeu, B. P. (1901) Cine sunt albanezii, ripublished in B.P. Hașdeu Studii și lingvistcă și filologie, II, Minerva, Bucharest, 1988 (v.470)

Hirt, H. (1967) Le latin vulgaire, Paris

Ismajli, R. (1987) Huazime latine të gjuhës shqipe, Rilindja, Prishtine

Ismajli, R. (2012) Shqipja dhe rumanishtja, ASHAK, Prishtine

Karagjozi-Kore, M. (2009) Parallèle entre les proverbes albanais et roumains,Editura Muzeul Literaturii Române, Vol. 6 Bucureşti, v. 61-68

Marcus A. Gabinschi, Chişinău (2012) Saktesime rreth fondit leksikor te quajttur "rumuno shqiptar" ASHAK, Prishtine

Mihǎescu, H. (1966) Les éleménts latins da la langua albanaise, Revue des études sud -est européennes, Bucarest

Mišesca Tomic O. (2006). Balcan shprahchbund, morpho-sintactic features, Springerfield, Netherland The New Dictionary of the Romanian Language, Litera Internaţional Publishing House.

Paci, E. (2012) Elemente latine në shqipe dhe në rumanishte (veshtrim semantik dhe tipologjik) ne Conference: Albanian and Balkan Languages, Prishtine

Pasku, G. (1916). Sufixule Romaneşti. Editiunea Akademici Romană, Bucareşt

Pelegrini, Xh, B. (1982). Disa vwzhgime mbi elementin latin tw shqipes, SF, nr. 3, Tirana

Philippide, O (1927). Ce spun limbile româna și albaneză, Viața Românească, Jash

Rosetti, A. (1930). Cercetări asupra graiului românilor din Albania, Buchareșt

Russu, I. (1967). Limba traco-dacilor, published in at Editura Ştiinţifică, Bucharest

Sandfeld, C. (1930). Linguistique balkanique, problemes et resultats. Paris.

Tagliavini, C. (1932) Divagazioni semantiche rumene e balcaniche (Dal nome proprio al nome comune), in Archivum Romanicum, XVI

Vraciu, A. (1980). Limba daco-geţilor, published at Editura Facla, Timişoara. 
